\title{
27 OPENING PUBLIC ADMINISTRATION: Exploring Open Innovation Archetypes and Business Model Impacts
}

\author{
Joseph Feller \\ Patrick Finnegan \\ Olof Nilsson \\ University College Cork \\ Cork, Ireland
}

\begin{abstract}
This work-in-progress paper presents an exploration of a network of Swedish municipal authorities. Within this network, we have observed a move from isolated innovation to leveraging inflows and outflows of knowledge in a manner characteristic of the open innovation paradigm. This paper presents a characterization of these knowledge exchanges using an existing framework of open innovation archetypes, as well as an initial description of the business model impacts of this innovation approach on the participant municipalities, and the enabling role of information technology. The paper concludes by drawing preliminary conclusions and outlining ongoing research.
\end{abstract}

Keywords Open innovation, business model, public administration interorganizational network

\section{INTRODUCTION}

Western civilizations have tended to respect and reward individual rather than group initiatives. Such individualism extended to Western organizations, which consider their competitors, and very often their suppliers, as the enemy (Opper and Fersko-Weiss 1992; Roper and Weymes 2007). This is reflected in organizational theory as researchers

Please use the following format when citing this chapter:

Feller, J., Finnegan, P., and Nilsson, O., 2008, in IFIP International Federation for Information Processing, Volume 287, Open IT-Based Innovation: Moving Towards Cooperative IT Transfer and Knowledge Diffusion, eds. León, G., Bernardos, A., Casar, J., Kautz, K., and DeGross, J. (Boston: Springer), pp. 483-500. 
traditionally view organizations as single entities characterized by bureaucratically determined hierarchical structures that operate by placing individuals in predefined functional roles (Czarniawaska-Joerges 1992). Consequently, organizational strategies have traditionally focused on neutralizing competitors to gain control over their buyers or suppliers (Porter 1985); although recognizing that some cartels did operate. In the past two decades, competitive pressures have focused greater attention on cooperative ventures with partners (Henderson 1990; Reid et al. 2007), even if some relationships are based more on power than cooperation (Webster 1995). In addition, developments in the production and use of complex product/service offerings (Davidow and Malone 1992) and the desire to focus on providing whole products (Moore 1999) have resulted in organizations with similar goals aligning themselves in IT-mediated partner networks in order to meet consumer requirements (Okamura and Vonortas 2006; Stafford 2002).

Despite the continuing importance of interorganizational cooperation in relation to servicing consumer needs for products and services (Okamura and Vonortas 2006), organizations have been slow to harness the same type of external cooperation in relation to innovation (Lane and Probert 2007). Nevertheless, innovation is the result of combining different knowledge sets (Nonaka et al. 2003; Tidd et al. 2005), and such knowledge is frequently to be found outside the organization (Chesbrough 2003; De Wit et al. 2007). However, with the exception of notable examples of collective invention (Allen 1983; von Hippel 1987), organizations have been slow to engage in open innovation (Chesbrough 2003). In addition to worries about the quality and suitability of external ideas, organizations have resisted cooperative approaches to innovation due to perceived competitive necessities and issues relating to organizational control (Chesbrough 2004). In the commercial area, adopting an open innovation process "includes various perspectives: (1) globalization of innovation, (2) outsourcing of R\&D, (3) early supplier integration, (4) user innovation, and (5) external commercialization and application of technology" (Gassmann 2006, p. 224). Consequently, in order to move to an open innovation, there is a need for organizations to adopt business models (Chesbrough and Schwartz 2007) that utilize "both external and internal ideas to create value, while defining internal mechanisms to claim some portion of that value" (Chesbrough 2003, p. xxiv).

There have been numerous examples of the successful application of open innovation research and development processes in commercial settings such as consumer electronics (Blau 2007), pharmaceuticals (Lane and Probert 2007), as well as automobiles and computer hardware (Gwynne 2007). While open innovation practices are not limited to "high-tech" sectors (Chesbrough and Crowther 2006), there is a paucity of research on the application of open innovation outside the commercial environment.

This paper presents an exploration of a network of Swedish municipal authorities. Within this network, we have observed a move from isolated innovation to leveraging inflows and outflows of knowledge in a manner characteristic of the open innovation paradigm. This paper presents a characterization of these knowledge exchanges using an existing framework of open innovation archetypes, describes the impact of this innovation approach on the business models of the participant municipalities, and discusses the enabling role of IT. The remainder of the paper is structured as follows. In section 2, we present a theoretical grounding for the study in the work of Gassmann and Enkel (2004) on open innovation archetypes and Osterwalder et al. (2005) on business models. Section 3 describes the research methodology employed and section 4 presents a descrip- 
tion of the case site. As this research is still in progress, we describe our initial findings in section 5, and discuss our preliminary conclusions and ongoing research in section 6.

\section{THEORETICAL GROUNDING}

This section presents the theoretical grounding for the study. We examine how extant research on business models and networks can frame our understanding of organizations seeking to form an ecosystem to exploit cooperatively developed innovation.

Interorganizational networks are critical for leveraging open innovation (Vanhaverbeke and Cloodt 2006). Participants in interorganizational networks believe that collaboration will result in adaptive efficiency, "the ability to change rapidly and at the same time provide customized services or products, and at low cost" (Alter and Hage 1993, p. 274). As shown in Figure 1, Gassmann and Enkel (2004) propose three core open innovation processes that illustrate the interconnectivity between an organization and its external network of partners:

1. The outside-in process: the sourcing of knowledge from external parties such as suppliers, customers, etc.

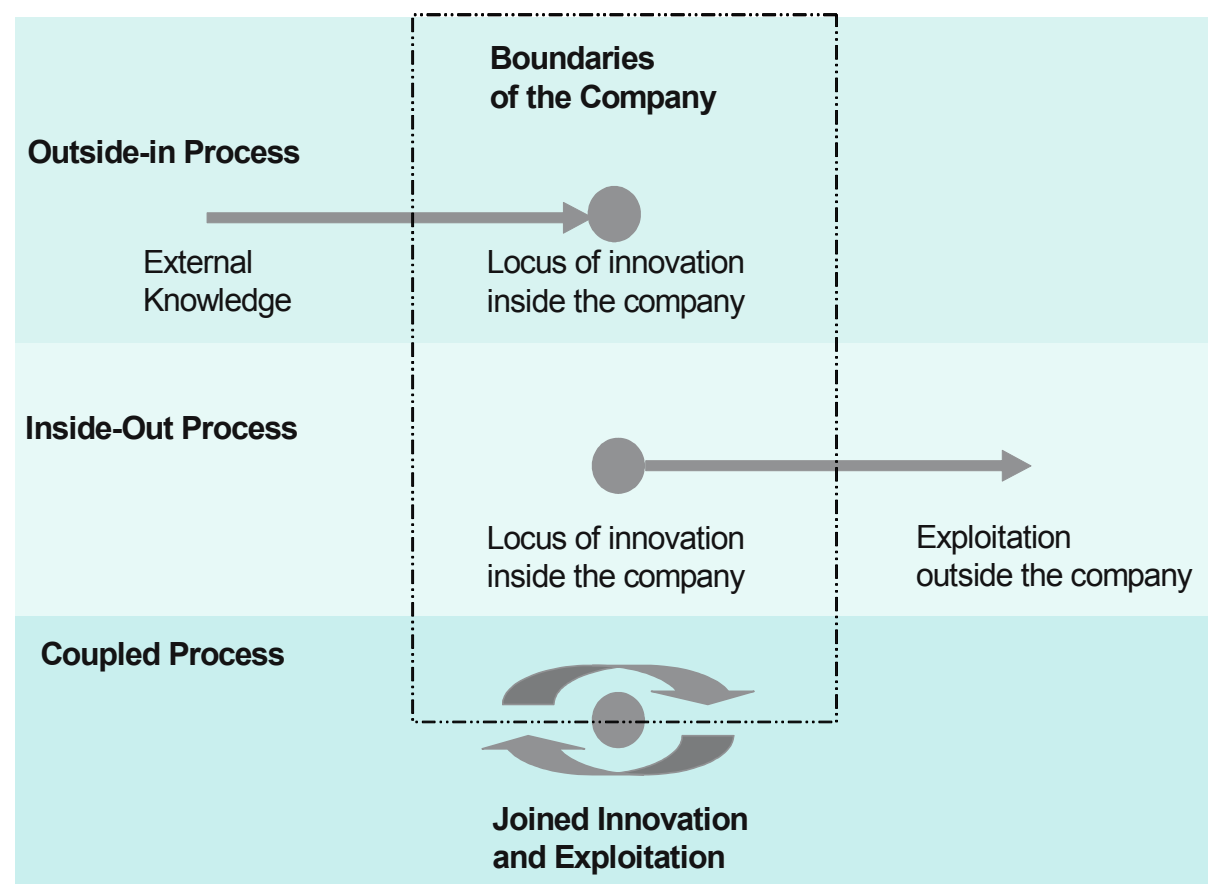

Figure 1. Three Core Processes for Open Innovation (Source: Gassmann and Enkel 2004, p. 6, used with permission of the authors) 
2. The inside-out process: earning revenue by transferring ideas to the outside environment and allowing others to exploit them.

3. The coupled process: a combination of outside-in and inside-out processes by forming an alliance with external partners that can provide complementary expertise. An interorganizational network is a social action system as it exhibits the fundamental principles of any organized form of collective behavior. These are

- Members aim to achieve collective and self-interest goals

- The division of tasks and functions among members creates interdependent processes

- The cooperative entity can act as a unit and has a separate identity from its members (Van de Ven 1976)

In order to operate, a social system imposes a structure and processes upon its members. Structure refers to administrative arrangements that establish role relationships among members. Process refers to the direction and flow of activities among members. The structural dimensions of an interorganizational relationship can be characterized by its degree of formalization, complexity, and centralization. The process dimensions of such a relationship are characterized by the direction, intensity, and variability of resource and information flows (Van de Ven 1976). Table 1 characterizes the three open innovation processes discussed above and provides examples of interorganizational interconnectivity related to each.

As is evident from Table 1, the changing locus of innovation evident within and across organizational boundaries resulting from applying open innovation processes has implications for an organization's strategic direction and operational activities. The architecture that represents the business logic connecting strategic and operational acti-

Table 1. Characterizing the Three Core Processes for Open Innovation (Adapted from Gassmann and Enkel 2004)

\begin{tabular}{|c|c|c|}
\hline Process & Characteristic & Example \\
\hline $\begin{array}{l}\text { Outside- } \\
\text { in Process }\end{array}$ & $\begin{array}{l}\text { - Low tech industry for similar technology } \\
\text { acquisition } \\
\text { - Act as knowledge brokers and/or } \\
\text { knowledge creators } \\
\text { - Highly modular products } \\
\text { - High knowledge intensity }\end{array}$ & $\begin{array}{l}\text { - Earlier supplier integration } \\
\text { - Customer co-development } \\
\text { - External knowledge sourcing } \\
\text { and integration } \\
\text { - In-licensing and buying } \\
\text { patents }\end{array}$ \\
\hline $\begin{array}{l}\text { Inside-out } \\
\text { Process }\end{array}$ & $\begin{array}{l}\text { - (Basic) Research-driven company } \\
\text { - Objectives like decreasing the fixed costs } \\
\text { of R\&D, branding, setting standards via } \\
\text { spillovers }\end{array}$ & $\begin{array}{l}\text { - Bringing ideas to market } \\
\text { - Out-licensing and/or selling IP } \\
\text { - Multiplying technology } \\
\text { through different applications }\end{array}$ \\
\hline $\begin{array}{l}\text { Coupled } \\
\text { Process }\end{array}$ & $\begin{array}{l}\text { - Standard setting (predominant design) } \\
\text { - Increasing returns to industry through } \\
\text { multiplying technology } \\
\text { - Alliance with complementary Partners } \\
\text { - Complementary products with critical } \\
\text { interfaces } \\
\text { - Relational view of the firm }\end{array}$ & $\begin{array}{l}\text { - Combining outside-in and } \\
\text { inside-out processes } \\
\text { - Integrating external } \\
\text { knowledge and competencies } \\
\text { and externalizing own knowl- } \\
\text { edge and competencies }\end{array}$ \\
\hline
\end{tabular}


vities is referred to as a business model (Osterwalder et al. 2005). Indeed, understanding the business model implications of open innovation is central to its exploitation (Chesbrough 2003; Chesbrough and Appleyard 2007; Chesbrough and Schwartz 2007).

Timmers (1999) argued that architectures for business models can be identified through the deconstruction and reconstruction of the value chain. Value chain elements are identified, as are the possible ways that information can be integrated both within the value chain and between the respective value chains of interacting parties within the interorganizational network. Furthermore, as more advanced information standards are introduced, levels of collaboration between organizations can be achieved that were previously only possible within a vertically integrated hierarchical intra-organizational structure (Evans and Wurster 2000). Indeed, it is evident from the work of Mahadevan (2000), of Osterwalder et al., and of Timmers that business models must examine both strategic and operational value-adding activities in the context of a an interorganizational network.

In developing a conceptual framework for our study, we utilize the work of Osterwalder et al., who propose a business model ontology that focuses on four aspects of the organization: product innovation, infrastructure management, customer relationship, and financials (Table 2). The application of the Osterwalder et al. framework to open innovation is not completely new. Research such as Feller et al. (2008) has applied the framework to the business model implications of companies forming a business network to leverage externally produced open source software (OSS). OSS is notable example of open innovation (West and Gallagher 2006).

Table 2. Business Model Pillars and Components (Source: Osterwalder et al., p. 18, (C) Association for Information Systems. Used with permission.)

\begin{tabular}{|l|l|l|}
\hline \multicolumn{1}{|c|}{ Pillar } & \multicolumn{1}{|c|}{$\begin{array}{c}\text { Business Model } \\
\text { Building Block }\end{array}$} & \multicolumn{1}{c|}{ Description } \\
\hline \multirow{3}{*}{ Product } & Value Proposition & $\begin{array}{l}\text { Gives an overall view of a company's bundle of } \\
\text { products and services. }\end{array}$ \\
\cline { 2 - 3 } $\begin{array}{l}\text { Customer } \\
\text { Interface }\end{array}$ & Target Customer & $\begin{array}{l}\text { Describes the segments of customers a company } \\
\text { wants to offer value to. }\end{array}$ \\
\cline { 2 - 4 } & Distribution Channel & $\begin{array}{l}\text { Describes the various means of the company to } \\
\text { get in touch with its customers. }\end{array}$ \\
\cline { 2 - 4 } & Value Configuration & $\begin{array}{l}\text { Explains the kind of links a company } \\
\text { establishes between itself and its different } \\
\text { customer segments. }\end{array}$ \\
\hline \multirow{3}{*}{$\begin{array}{l}\text { Infrastructure } \\
\text { Management }\end{array}$} & Core Competency & $\begin{array}{l}\text { Outlines the competencies necessary to execute } \\
\text { the company's infrastructure business model. }\end{array}$ \\
\cline { 2 - 4 } & Partner Network & $\begin{array}{l}\text { Portrays the network of cooperative agreements } \\
\text { with other companies necessary to efficiently } \\
\text { offer and commercialize value. }\end{array}$ \\
\hline Financial \\
Aspects & Cost Structure & $\begin{array}{l}\text { Sums up the monetary consequences of the } \\
\text { means employed in the business model. }\end{array}$ \\
\cline { 2 - 3 } & Revenue Model & $\begin{array}{l}\text { Describes the way a company makes money } \\
\text { through a variety of revenue flows. }\end{array}$ \\
\hline
\end{tabular}




\section{RESEARCH OBJECTIVE AND METHOD}

The objective of this study is to explore a network of public administration authorities in which municipalities collaborate with each other and external parties to accelerate the creation and exploitation of internal innovations.

This type of network is in keeping with the thinking of Chesbrough and Crowther (2006) on open innovation processes. However, in order to provide a more focused consideration of the type and impact of the innovation processes, we utilize the work of Gassmann and Enkel (2004) on archetypes of open innovation processes and Osterwalder et al. (2005) on business models to formulate the following research questions:

RQ1: How do network participants leverage outside-in, inside-out, and coupled open innovation processes?

RQ2: What is the impact of open innovation activities on the business models of the network participants?

Given the exploratory nature of this research and the need to obtain rich data in a complex interorganizational context, a case study approach was adopted.

A case study examines a phenomenon in its natural setting, employing multiple data collection methods to gather information from a few entities. The boundaries of the phenomenon are not clearly evident at the outset of the research and no experimental control or manipulation is used (Benbasat et al. 1987, p. 370).

Cases are most appropriate when the objective involves studying contemporary events, without the need to control variables or subject behavior (Yin 2003).

Our case study seeks to approximate reality (Guba 1990) using methods that emphasize the verification of existing knowledge and the discovery of new knowledge (Denzin and Lincoln 2000). Our method is thus consistent with the case study approach of Benbasat et al. (1987) and of Yin (2003) in that we study the phenomenon in its natural setting, employing multiple data collection methods to gather information from a few entities, without employing experimental control or manipulation. We, thus, follow in the tradition of Eisenhardt (1989) and of Madill et al. (2000) by seeking to reveal preexisting, relatively stable, and objectively extant phenomena and the relationships among them.

The case study site was chosen as a useful exemplar of the use of open innovation processes in public administration. The study began in January 2008 and is ongoing at the time of writing. The researchers first conducted an archival search of public domain material on the network and its participant municipalities. Based on this preliminary analysis, a case study protocol was prepared (Yin 2003). Having secured the cooperation of five of the six participating municipalities, interviews with key informants in the largest municipality in the network, the Municipality of Sundsvall, began in February 2008. The choice of the interviewees was based on

1. Willingness to cooperate: In order to obtain useful material, it was necessary for a potential interviewee to be interested in the study and willing to cooperate. 
2. History of network involvement: Interviewees had to be involved in the ingoing network planning and/or activity over a period of time.

3. Seniority: In order to get contextual material on strategy and experience with network activities, it was necessary to speak with senior staff within each partner firm.

The interviews, following an interview guide (Patton 1980) were of 50 to 60 minutes duration and conducted in Swedish by telephone. The interviews were transcribed and translated by one of the authors and followed up by e-mail to clarify and refine issues that emerged during the process. The respondents verified the accuracy of the transcripts. Interviews were complemented by reviews of official documents provided by the interviewees. The documents included policy statements, project reports, and official statistics published by the municipalities in the region, and by national governmental authorities. Content analysis was then carried out on both the interview and document data sets. A coding system was derived using the frameworks provided by Gassmann and Enkel and by Osterwalder et al., and a two-phase coding process was employed (Miles and Huberman 1994). During the first-level coding phase, each segment of the interview/documentation data was summarized and labeled. This was followed by a pattern coding process in which the segments of data were organized, analyzed, and synthesized within the themes/concepts embedded in the theoretical framework. While the emphasis of the first-level coding phase was on description, the pattern coding process focused on explanation. The analysis of the official documents was used primarily to supplement the data gathered through the interviews and to provide context.

\section{CASE ENVIRONMENT}

Traditionally, Swedish authorities have had almost a monopoly position in providing services to their citizens. Folkhemmet or "the people's home" (Tilton 1990, p. 125), is a concept that has played an important role during the building of the welfare state. The dominant paradigm has been that the state "takes care of you," and no one should make a profit on people's rights and needs. The welfare model is built on a taxation system which has both a broad basis of taxation, high taxation burden, and income redistribution (Andersen 2004). It is considered that a commercial or private-sector organization should put their profit interest before the public good, and is thus not suitable for running public services (e.g., schools, kindergartens, hospitals, or homes for the elderly). Swedish public authorities are organized at three levels: local, regional, and national. The Administrative Procedure Act, the principle of public access to official documents, and the Swedish Local Government Act (Government Offices of Sweden 2007a) are some of the regulations that form the framework that governs public administration activities and influences the municipalities' strategies and actions. The keywords for the Swedish authorities are openness and decentralization. In addition, the system requires that responsibility for the activities and the decision making should be located as close as possible to those concerned as such decentralization makes it possible to adjust activities to local conditions.

Municipal administration represents approximately 70 percent of the public administration in Sweden (Government Offices of Sweden 2007b). The 290 municipalities in 
Sweden are all organized in a similar way: a municipality council as the highest decision-making body, a municipal executive board, and a number of boards responsible for the different areas of activity. The council consist of representatives elected in general elections every fourth year; boards are comprised of politically appointed representatives. Connected to every board is an office with civil servants charged with putting the board's decisions into practice. The municipality council takes decisions concerning the municipality's overall annual budget, as well as the level of municipality tax and fees. Each board is allocated a budget, which by law must balance (Swedish Government 2001).

This system of public administration has been subject to major overhaul in recent years. A governmental bill proposed in 2000 (Swedish Government 2000) outlined the ambition that Sweden should become "the first information society for all." This goal includes a demand upon public authorities at all levels to transform to 24/7 authorities (i.e., develop Internet-based services available day and night, year-around).

Traditionally, the municipalities have considered other municipalities as competitors in the struggle to attract visitors, migrants, and new business establishments. Escalating costs, an ageing and in many areas decreasing population, as well as increasing globalization and mobility are leading to public administration needing new ways to operate. Of particular interest, in recent years several municipalities have formed networks with the aim of sharing ideas, experiences, innovations, and software. Many of the public administration networks that have emerged can be seen as examples of open innovation processes in that they use "purposive inflows and outflows of knowledge to accelerate internal innovation, and expand the markets for external use of innovation, respectively" (Chesbrough and Crowther 2006, p. 2).

\subsection{The Sundsvall Region}

The Sundsvall Region (Sundsvallsregionen) was founded in 2004 as a cooperative network of six Swedish municipalities, situated geographically in the middle of Sweden (Figure 2). The idea behind the Sundsvall Region is that, through cooperation, synergetic effects will strengthen both the individual municipalities' and the region's ability to provide services to citizens as well as the prerequisites for sustainability and growth.

The six municipalities, Härnösand, Timrå, Sundsvall, Ånge, Nordanstig, and Hudiksvall, vary in character. The variety of labor markets, attractive shopping centers, good communications infrastructure, the county hospital, the university and the large population $(94,044)$ all contribute to the centrality of the municipality of Sundsvall, which must be considered as the hub in the Region. The municipality of Härnösand $(25,227$ inhabitants) is characterized by small towns, but is the administrative center for the County of Västernorrland, and also has a university campus (which is the largest employer in the public sector). The municipality of Timra (17,747 inhabitants) is a small coastal municipality dominated by the forest industry. The municipality of Ånge $(10,692$ inhabitants) is the only inland municipality within the network. It is a sparsely populated ( 3 persons $/ \mathrm{km}^{2}$ ) rural area and has lost almost half of its population since 1960 . The municipality of Nordanstig is the smallest municipality in the Sundsvall Region, both in terms of area and population $(9,847)$. Like Ånge, the municipality is a sparsely populated rural area. Finally, the municipality of Hudiksvall $(37,004)$, situated along the coast com- 


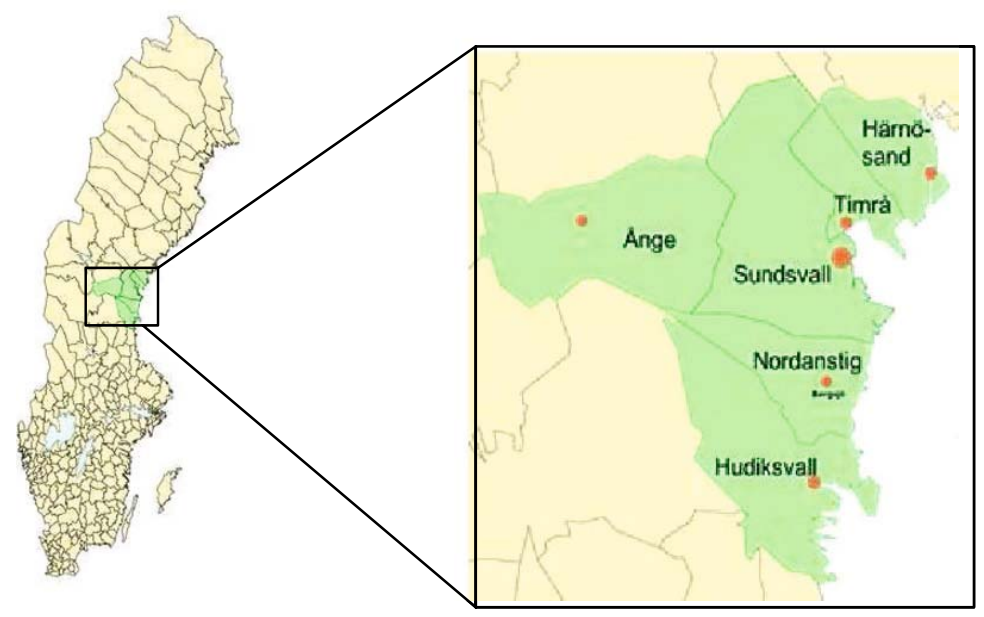

Figure 2. Geography of Sundsvall Region

prises small towns. The private economic life is dominated by the forest and engineering industries, and the public sector employs almost 38 percent.

The vision for the Sundsvall region has been expressed as follows:

In a region with 200,000 inhabitants we can through cooperation create better conditions for individuals and companies, create strong and sustainable growth, and increase our competitiveness. Härnösand, Timrå, Sundsvall, Ånge, Nordanstig and Hudiksvall; we are all unique and independent municipalities. Together we are now building a strong joint identity for our region, while putting every municipality's uniqueness forward. It will give us the strength to become a successful part, not only of Sweden but also of Europe. (Kortfattat om Sundsvallsregionen $)^{1}$

\section{FINDINGS}

Our study revealed that the three open innovation process archetypes described by Gassmann and Enkel (2004) were evident in both the municipal and network level activities in the Sundsvall Region. Our initial research focused on three specific projects (see Table 3). Figure 3 depicts the inside-out, outside-in, and coupled innovation processes at work, using the development and subsequent deployment of the ECHOES software project (described later in this section) to illustrate the inflows and outflows of knowledge and exploitation.

${ }^{1} \mathrm{Http} / /$ www.sundsvall.se/download/18.2980dd9910f81b06233800039/kortfattat_36sidor_ 061211.pdf, 2006. 


\section{Table 3. Examples of Open Innovation Projects}

\begin{tabular}{l} 
ECHOES - an open source web tool for parent-teacher communication developed in coopera- \\
tion with Åkroken Science Park, the Child Service and Education Office at the Municipality \\
of Sundsvall, the CITIZYS Research Group at Mid Sweden University, and a private IT \\
consultant company. \\
\hline Pensiostorm - an on-going project for developing a web portal for the elderly, based on open \\
source components. The partners in the project are Åkroken Science Park, the Municipality of \\
Sundsvall, CITIZYS Research Group, The National Government Employee Pensions Board \\
(SPV), and the IT consultant company WM-Data (LogicaCMG). \\
\hline Digital Age in Rural and Remote Areas (DARRA) - a project aiming to decrease the digital \\
divide in remote and rural areas among the partner regions, through boosting the usage of ICT \\
by SMEs and the public sector, and improve the overall regional competitiveness. Participating \\
regions are Lapland and Kainuu in Finland, Västernorrland in Sweden, Sogn og Fjordane in \\
Norway, Donegal in Northern Ireland (UK), and Mid West Region in Ireland. \\
\hline
\end{tabular}

\section{OUTSIDE OF REGION (National and International Level - Sweden, France, Thailand and Canada}

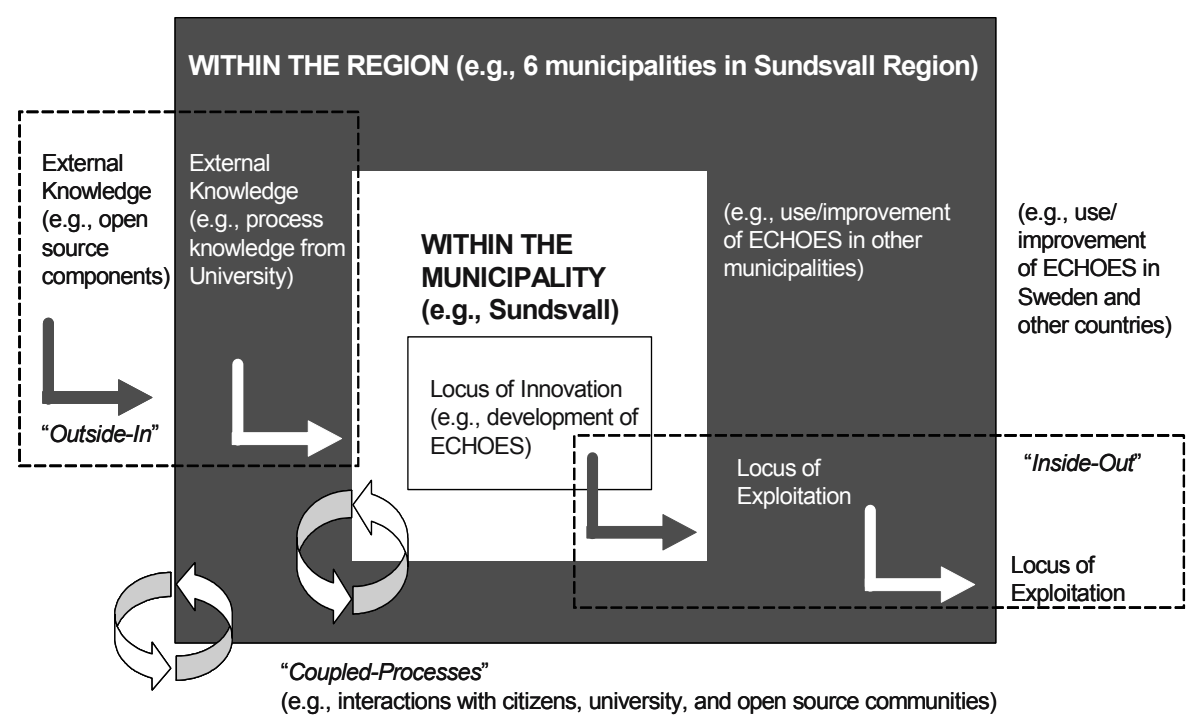

Figure 3. Open Innovation Flows in the Network

\subsection{The Open Innovation Process Archetypes}

The outside-in process: Individual municipalities have traditionally been more receptive to the concept of outside knowledge flowing in than to that of internal knowledge flowing out, as organizational controls around such knowledge are still quite "closed" in character. External knowledge has been welcomed and used in the development of systems and the performance of operational activities, but the willingness to share innovations or experiences was been limited; traditionally, other municipalities 
were considered as competitors. That situation is now undergoing a change toward openness and cooperation, although many in the public administration have a wait-and-see attitude about open source solutions. For example, the CEO of one municipality describes their engagement with a national collaborative software repository as

\begin{abstract}
When we look at eGovforge.org ${ }^{2}$ there are not so much activity around the applications that have been uploaded, but I think that it is because this area (Open Source) is still pretty new in the public sector here in Sweden. I believe that we soon would see a rapid development in this area.
\end{abstract}

The outside-in process also includes an enhanced cooperation with academic institutions, neighboring municipalities, and the commercial sector. Indeed, in keeping with the increasing pace of globalization, innovation processes increasingly involve cooperation with organizations outside the country. By leveraging external knowledge, municipality's not only avoid "reinventing the wheel" by investing resources in innovation challenges that have already been addressed by others, but are also able to fill the gaps within their own internal set of competencies.

The strategic investigator at the Mnicipality Executive Board's Executive Office state,

There is a more open attitude nowadays in which we share ideas, and a number of networks to facilitate this sharing have been launched. In some areas, such as efforts to attract companies to the municipality, it has been difficult to be open or to cooperate since we compete with other municipalities for business establishments and job opportunities. But we have started discussions to also become more open and cooperative in this area as well. If, for example, we have discussions with a company and find it to be unsuitable for us, it is better for us if one of our neighbors gets it than if it goes somewhere outside the region.... We also work developing models for how to run and steer the municipality, and in that area we are very open and share experiences and ideas with others. If we put questions to other municipalities regarding this, it is very rare that they don't share their experiences with us.

The inside-out process: The municipality's main task to-date has been to serve the citizens and companies within the municipality, and the exploitation of innovation has been secondary to the operational concerns of organizing and delivering services within budget constraints. However, perceptions of how services should be organized and provided are changing, influenced by factors such as an ageing population, an increased mobility among people and companies, globalization and computerization. Public administration is a nonprofit endeavor; nevertheless, the external exploitation of ideas is seen as potentially contributing to an increase in the municipality's revenues by a strengthened attractiveness for migration and new establishment. As expressed by the CEO,

${ }^{2}$ eGOVForge.org is a Swedish national repository of open source software designed to "meet the demand for increased cooperation both between and inside...government bodies" and provides mechanisms for the "conversion of software developed within the public sector into open software," increasing the deployment of this software and stimulating collaborative development and open formats and standards" (see http://eGOVForge.org). 
I don't see us [the municipality] as just consumers of free software, or that we use the open source community without giving anything back. I, myself, have been active for many years in introducing open software in schools also at a national level. For example, we were a group that was given the task to start and handle a site called "Utbytet" [the exchange], which was the first Swedish site [2003] for exchange of open software and experience in the school area in Sweden. Our contribution to the OS community has been an active use and promotion which have contributed to "break the ice", but also source code like Parent-Teacher Meeting.

The coupled process: The open innovation processes in the public administration context examined can be best understood in terms of the interactivity characterizing the coupled process archetype. The municipalities in the network work together in an alliance, but are not locked-in by this cooperation. One example of this cooperation is the development of the software to support Parent-Teacher communication (the ECHOES project), a web-based application for connecting homes and schools. The project was a joint project with Åkroken Science Park, the Child Service and Education Office at the Municipality of Sundsvall, the CITIZYS Research Group at Mid Sweden University, and a private IT consultant company as partners. Open source components were used during the whole process, and after test and evaluation the application was released in the software pool eGovforge.org (an initiative for collaboration through open software development for the public sector in Sweden) under an open source license. The successful project has lead to initiation of a new project, Pensiostorm, a web portal for the elderly, which now is under development. Like ECHOES, this new project seeks to build on open source components. The partners are Åkroken Science Park, Municipality of Sundsvall, CITIZYS Research Group, The National Government Employee Pensions Board (SPV), and the IT consultant company WM-Data (LogicaCMG).

The Municipality of Sundsvall is also a member in a common foundation for eservice development called Sambruk, which includes both cooperation around a selection of e-services as well as cooperation around the knowledge and technical components required for developing and running e-services. The initiative is in line with the Swedish government's ambitions to move to a coordinated public sector with integrated eservices. Finally, the municipality is a member of $e$-Ringen, a network for sharing ideas and experiences regarding e-administration in the public sector. According to the CEO,

I can see a future where more municipalities jointly contract suppliers and developers, and then give a more mature and developed product back to the OS community. For example, our municipality together with five other municipalities is developing an invoice module in open source that later should be uploaded at eGovforge.org for public use.

\subsection{The Impact on Business Models}

We have a preliminary understanding of the impact of openness on the business models of the participating municipalities in the Sundsvall Region, summarized in Table 4. 


\begin{tabular}{|c|c|c|}
\hline \multicolumn{2}{|c|}{ Business Model Pillar } & \multirow{2}{*}{$\begin{array}{l}\text { Effect of Sundsvall Region member's Business Models } \\
\text { Innovation has resulted in an extended geographic coverage, } \\
\text { a wider range of services, an extended offer of living, educa- } \\
\text { tion, work and leisure, raised attractiveness for migration, } \\
\text { start-ups, tourism and a strengthened bargaining position. }\end{array}$} \\
\hline Product & $\begin{array}{l}\text { Value } \\
\text { Proposition }\end{array}$ & \\
\hline \multirow[t]{3}{*}{$\begin{array}{l}\text { Customer } \\
\text { Interface }\end{array}$} & $\begin{array}{l}\text { Target } \\
\text { Customer }\end{array}$ & $\begin{array}{l}\text { Shift from existing residents to a collaborative approach to } \\
\text { attracting inwards-migration, company establishments, and } \\
\text { visitors. }\end{array}$ \\
\hline & \begin{tabular}{|l|} 
Distribution \\
Channel \\
\end{tabular} & $\begin{array}{l}\text { Collaborative implementation of multiple IT enabled channels } \\
\text { for the delivery of citizen services. }\end{array}$ \\
\hline & Relationship & Deeper engagement with a wider range of customers. \\
\hline \multirow{3}{*}{$\begin{array}{l}\text { Infrastructure } \\
\text { Management }\end{array}$} & $\begin{array}{l}\text { Value } \\
\text { Configuration }\end{array}$ & $\begin{array}{l}\text { Value shop configuration. The network strengthens the possi- } \\
\text { bilities to fulfill customer needs. }\end{array}$ \\
\hline & $\begin{array}{l}\text { Core } \\
\text { Competency }\end{array}$ & $\begin{array}{l}\text { An extended base of core competencies, possibility to share } \\
\text { specialist competencies. }\end{array}$ \\
\hline & $\begin{array}{l}\text { Partner } \\
\text { Network }\end{array}$ & $\begin{array}{l}\text { The network increases the partners' ability to find solutions } \\
\text { inside the network, and strengthen bargaining position. Co- } \\
\text { operation instead of competition. }\end{array}$ \\
\hline \multirow[t]{2}{*}{$\begin{array}{l}\text { Financial } \\
\text { Aspects }\end{array}$} & $\begin{array}{l}\text { Cost } \\
\text { Structure }\end{array}$ & $\begin{array}{l}\text { Enables cost-sharing among the municipalities (e.g., emer- } \\
\text { gency services, education, water and sewer, public trustee } \\
\text { office). }\end{array}$ \\
\hline & $\begin{array}{l}\text { Revenue } \\
\text { Model }\end{array}$ & $\begin{array}{l}\text { A raised attractiveness increases the incomes, and sharing } \\
\text { resources reduces costs. }\end{array}$ \\
\hline
\end{tabular}

The Sundsvall Region network strengthens the partner municipalities' ability to offer present and potential customers an enhanced value (value proposition) by providing the different municipalities' unique features as one "product." The region covers a geographical area that includes a wide choice of living conditions, from coast to inland, and from big and small towns to countryside. The municipalities' different characteristics regarding commercial and industrial life and education constitute a single labor and educational market with many possibilities. The cooperation increases the attractiveness for migration while a broad labor market often is a crucial factor for couples. The fact that the network brings synergetic effects means that the smaller municipalities within the network can compete with bigger ones outside in striving for growth and sustainability. Acting as one "brand" also enhances the possibilities for state-funded infrastructure investments (such as roads and railways), which in turn raises the attractiveness of the region. According to a recent report,

The Sundsvall Region, northern Sweden's biggest labor market with its own university, is in many ways the best alternative to the metropolises. (Kortfattat om Sundsvallsregionen)

While current inhabitants and companies located within the region remain the primary target customers, branding the Region also raises the opportunity to successfully market the member municipalities to a broader customer base, for example, attracting 
tourists, day visitors, potential migrants and companies from both national and international locations.

In pace with the computerization of the society and the raised demands for eservices, the distribution channels have been extended. Today the Internet plays one of the leading roles in communication with existing and potential customers. It is believed that one joint web site that acts like a "one-stop-shop" or gateway to the region will gain more attention than six separate ones.

The relationship with the citizens is important in order to keep them as customers. By building a region, it is believed that citizenship identity and incentives for staying in the area are strengthened.

By acting as one region instead of six rival municipalities the necessary core competency is enhanced. A number of the municipalities' tasks and services require specialist competences, which could be costly for a small municipality. By sharing these types of competences, the service level can be kept at a desired level, without turning to actors outside the network.

The partner network facilitates the municipalities' ability to find solutions inside the region. It also strengthens the bargaining position to act as a region (rather than as a single municipality) while dealing with potential contractors. In contrast to the historical model in which each county council delivers transportation services in isolation, recent innovations in public transportation (as an example of the coupled-process archetype) demonstrate greater cooperation between municipalities, county councils, etc.; other coupled-process innovations (e.g., labor market innovations) also involve the county administrative board, the universities, and other public and private partners.

A key aspect of the network is the effect on the financial affairs to members. Revenues, which mainly are based on the municipalities' taxes and state grants, are directly dependent on the size of the population and the labor market. Due to current laws, these revenues cannot be transferred or shared between the members of the network, but accrue to the municipality where it is generated. Despite this, the region's increased attractiveness for companies, visitors, and tourists is likely to increase mobility within the region, and consequently bring benefits to all of the municipalities. As the strategic investigator reveals,

The municipality's revenues are more or less fixed and hard to influence. Today 73 percent of the municipality's revenues comes from the municipality tax, 5 percent from general state grants, 10 percent from fees and 12 percent from other sources [e.g., directed state grants, dividends from the municipality's own companies]. The way for us to increase our revenues is to make the municipality attractive so people settle here, but also to facilitate the establishment of companies within the municipality.

Cooperation enables cost-sharing among the municipalities, which affects the cost structure. There are a number of basic services (e.g., water and sewer services, emergency services, and education) where cooperation has reduced costs. The strategic investigator continues,

In other areas where we act, like elderly care, waste management, water supply and sewer management, private companies are not allowed to establish busi- 
ness unless the municipality gives permission. But, even if permission is given, it is the municipality that still has the overall responsibility, which implies that if the private company decides to withdraw their business, the municipality must be prepared to fill the gap. In all sectors where we are responsible by law we must have an overcapacity, or at least some kind of plan, to be able to handle these kinds of situations.

Additionally, IT costs have been growing in pace with computerization of systems and the development of e-services. One way to tackle these costs is a strategy for using open source solutions. The CEO argues,

For us as organization, another important reason for the use of open source tools in this project is that now we can sign a contract for operation, maintenance, and development with one supplier, and after the contract period we are free to contract another supplier without loosing control over the application when it is open source. We are also free to contract different suppliersone for the further development and another for the operation and maintenance.

\section{PRELIMINARY CONCLUSIONS AND ONGOING WORK}

While this research is still at an early stage, we have been able to draw some preliminary conclusions from the analysis of data gathered to date. The case study reveals that the growing movement toward more open innovation processes in Swedish public administration is being driven by two factors: (1) the changes in the national objectives regarding the delivery of public services and (2) the resource constraints (both in terms of limited budget and the internal availability of relevant capabilities) under which the municipal authorities must operate. In embracing "open innovation," we have seen evidence of all three open innovation process archetypes described by Gassmann and Enkel (2004). It is evident that in the early stages of moving toward this process, the management control activities within the authorities make these organizations most receptive to the outside-in approach. However, as the region studied has been engaged in this process for four years, we do see an increasing use of both inside-out and coupled processes, some with significant success (e.g., the ECHOES project).

However, effective participation in open innovation processes (particularly coupled processes) creates significant process, structural, and business model challenges in coordinating intermunicipality and interorganizational activities. While our work to date has focused on characterizing the collaborative processes emerging in this context, we have also found some evidence suggesting that there are significant business model changes associated with the effective exploitation of open innovation processes. The work to date represents an initial analysis of the implications of open processes for the product, customer interface, infrastructure management, and financial aspects of the public administration business model. Additionally, we found some evidence that collaborative IT platforms such as those used by open source communities (and deployed in the eGOVForge repository) have the potential to address these coordination challenges. It is noteworthy, however, that the municipalities have demonstrated a reluctance to embrace open source solutions for their operational systems; this reluctance appears to be 
driven by fear of the risks introduced by changing from their established (proprietary) platforms.

Our on-going work in this study comprises a closer examination of both the ways in which network participants engage in open innovation processes and the business model impacts of these activities. Future data gathering includes engagement with the remaining municipalities within the region, as well as a greater number and diversity of informants within each municipality.

\section{Acknowledgments}

This work has been funded by the Irish Research Council for the Humanities and Social Sciences (IRCHSS) through the O3C Business Models Project.

\section{References}

Allen, R. C. 1983. "Collective Invention,” Journal of Economic Behavior and Organization (4), pp. 1-24.

Alter, C., and Hage, J. 1993. Organisations Working Together, London: Sage Publications.

Andersen, T. M. 2004. "Challenges to the Scandinavian Welfare Model," European Journal of Political Economy (20:3), pp. 743-754.

Benbasat, I., Goldstein, D. K., and Mead, M. 1987. "The Case Research Strategy in Studies of Information Systems," MIS Quarterly (11:3), pp. 369-386.

Blau, J. 2007. "Philips Tears Down Eindhoven R\&D Fence," Research Technology Management. (50:6), pp. 9-10.

Chesbrough, H. 2003. Open Innovation: The New Imperative for Creating and Profiting from Technology, Boston: Harvard Business School Press.

Chesbrough, H. 2004. "Managing Open Innovation," Research \& Technology Management (47:1), pp. 23-26.

Chesbrough, H., and Appleyard, M. 2007. “Open Innovation and Strategy," California Management Review (50:1), pp. 57-76.

Chesbrough, H., and Crowther, A. K. 2006. "Beyond High Tech: Early Adopters of Open Innovation in Other Industries," $R \& D$ Management (36:3), pp. 229-236.

Chesbrough, H., and Schwartz, K. 1007. "Innovating Business Models with Co-Development Partnerships," Research Technology Management (50:1), pp. 55-59.

Czarniawaska-Joerges, B. 1992. Exploring Complex Organisations: A Cultural Perspective, London: Sage Publications.

Dawidow, W. H., and Malone, M. S. 1992. The Virtual Corporation, New York: HarperCollins.

Denzin, N. K., and Lincoln, Y. S. 2000. "The Discipline and Practice of Qualitative Research," in Handbook of Qualitative Research, N. K. Denzin and Y. S. Lincoln (eds.), Thousand Oaks, CA: Sage Publications.

De Wit, J., Dankbaar, B., and Vissers, G. 2007. “Open Innovation: the New Way of Knowledge Transfer?," Journal of Business Chemistry (4:1), pp. 11-19.

Eisenhart, K. M. 1989. "Building Theories from Case Study Research," Academy of Management Review (14:4), pp. 532-550.

Evans, P., and Wurster, T S. 2000. Blown to Bits: How the New Economics of Information Transforms Strategy, Boston: Harvard Business School Press.

Feller, J., Finnegan, P., and Hayes, J. 20008. "Delivering the 'Whole Product': Business Model Impacts and Agility Challenges in a Network of Open Source Firms," Journal of Database Management (12:2), pp. 95-108. 
Gassmann, O. 2006. "Opening up the Innovation Process: Towards an Agenda," R\&D Management (36:3), pp. 223-228.

Gassmann, O., and Enkel, E. 2004. "Towards a Theory of Open Innovation: Three Core Process Archetypes," in Proceedings of the R\&D Management Conference (RADMA), Sesimbra, Portugal, July 7-9 (http://www.alexandria.unisg.ch/EXPORT/DL/20417.pdf).

Government Offices of Sweden. 2007a. How Sweden Is Governed, IR 2007:010, Information Rosenbad, Stockholm, Sweden.

Government Offices of Sweden. 2007b. Handlingsplan för eFörvaltning - Nya grunder för IT-baserad versamhetsutveckling i offentligförvaltning, Dnr: Fi2007/1981/SF, The Ministry of Finance, Stockholm, Sweden.

Guba, E. G. 1990. "The Alternative Paradigm Dialog," in The Paradigm Dialog, E. G. Guba (ed.), Newbury Park, CA: Sage Publications.

Gwynne, P. 2007. "Open Innovation's Promise and Perils," Research Technology Management (50:6), pp. 8-9.

Henderson, J. C. 1990. "Plugging into Strategic Partnerships: The Critical IS Connection," Sloan Management Review, Spring, pp. 7-18.

Lane, C., and Probert, J. 2007. "The External Sourcing of Technological Knowledge by US Pharmaceutical Companies: Strategic Goals and Inter-organizational Relationships," Industry \& Innovation (14:1), pp. 5-25.

Madill, A., Jordan, A., and Shirley, C. 2000. “Objectivity and Reliability in Qualitative Analysis: Realist, Contextualist and Radical Constructionist Epistemologies," British Journal of Psychology (91:1), pp. 1-20.

Mahadevan, B. 2000. "Business Models for Internet Based E-Commerce: An Anatomy," California Management Review (42:4), pp. 55-69.

Miles, M. B., and Huberman, A. M. 1994. Qualitative Data Analysis (2 $2^{\text {nd }}$ ed.), Thousand Oaks, CA: Sage Publications.

Moore, G. 1999. Crossing the Chasm, New York: Harper-Perennial.

Nonaka, I., Keigo, S., and Ahmed, M. 2003. "Continuous Innovation: The Power of Tacit Knowledge," in International Handbook of Innovation, K. Shavinina (ed.),New York: Elsevier.

Okamura, K., and Vonortas, N. 2006. "European Alliance and Knowledge Networks," Technology Analysis \& Strategic Management (18:5), pp. 535-560.

Opper, S., and Fresko-Weiss, H. 1992. Technology for Teams: Enhancing Productivity in Networked Organizations, New York: Van Nostrand Reinhold.

Osterwalder, A., Pigneur, Y., and Tucci, C. 2005. "Clarifying Business Models: Origins, Present, and Future of the Concept," Communications of the AIS (15), pp. 1-43.

Patton, M. Q. 1980. Qualitative Evaluation and Research Methods, Newbury Park, CA: Sage Publications.

Porter, M. E. 1985. Competitive Advantage: Creating and Sustaining Superior Performance, New York: Free Press.

Reid, N., Carroll, M., and Smith, B. 2007. "Critical Steps in the Cluster Building Process," Economic Development Journal (6:4), pp. 44-52.

Roper, J., and Weymes, E. 2007. "Reinstating the Collective," Journal of Corporate Citizenship (26), pp. 135-144.

Stafford, T. 2002. "Trust, Transactions, and Relational Exchange: Virtual Integration and Agile Supply Chain Management," in Proceedings of the $8^{\text {th }}$ Americas Conference on Information Systems, R. Ramsower and J. Windsor (eds.), Dallas, TX, pp. 2365-2371.

Swedish Government. 2000. "Ett informationssamhälle för alla," Governmental bill 1999/2000: 86, Stockholm, Sweden.

Swedish Government. 2001. "God ekonomisk hushållning i kommuner och landsting," SOU 2001:76, The Ministry of Finance, Stockholm, Sweden. 
Tidd, J., Bessant, J., and Pavitt, K. 2005. Managing Innovation: Integrating Technological, Market and Organisational Change, Chichester, UK: Wiley \& Sons.

Tilton, T. 1990. The Political Theory of Swedish Social Democracy: Through the Welfare State to Socialism, Oxford, UK: Clarendon Press.

Timmers, P. 1999. Electronic Commerce: Strategies and Models for Business-to-Business Trading, Chichester, UK: Wiley \& Sons.

Van de Ven, A. H. 1976. "On the Nature, Formation and Maintenance of Relations among Organizations," Academy of Management Review (1), pp. 24-36.

Vanhaverbeke, W., and Cloodt, M. 2006. "Open Innovation in Value Networks," in Open Innovation: Researching a New Paradigm, H. Chesbrough, W. Vanhaverbeke, and J. West (eds.), Oxford, UK: Oxford University Press.

von Hippel, E. 1987. “Cooperation Between Rivals: Informal Know-How Trading,” Research Policy (16:6), pp. 291-302.

Webster, J. 1995. "Networks of Collaboration or Conflict? Electronic Data Interchange and Power in the Supply Chain," Journal of Strategic Information Systems (4:1), pp. 31-42.

West, J., and Gallagher, S. 2006. "Challenges of Open Innovation: The Paradox of Firm Investment in Open-Source Software," R\&D Management (36:3), pp. 319-331.

Yin, R. K. 2003. Case Study Research, Design and Methods ( ${ }^{\text {rd }}$ ed.), Newbury Park, CA: Sage Publications.

\section{About the Authors}

Joseph Feller, Ph.D., is a senior lecturer in Business Information Systems at University College Cork, Ireland. His research focuses on open source software and other forms of collaborative production. He has published four books and his work has appeared in leading international journals and conferences including Information Systems Research, Information Systems Journal, Journal of Strategic Information Systems, Journal of Database Management, the International Conference on Information Systems, the European Conference on Information Systems, and working conferences of IFIP. He has also published widely in practitioner-oriented publications and is a frequent contributor to the Cutter Consortium. He was program chair for the IEEE/ACM workshop series on open source software engineering (2001-2005) and the $3^{\text {rd }}$ International Conference on Open Source Systems (IFIP 2.13) and has edited several journal special issues on the subject of open source. He can be reached at jfeller@afis.ucc.ie.

Patrick Finnegan received his Ph.D. from the University of Warwick, England, and is currently a senior lecturer in information systems at University College Cork, Ireland. His research on interorganizational systems and electronic business has been published in a number of international journals and conferences, including Information Systems Research, Information Systems Journal, Information Technology and People, DATABASE, Journal of Information Technology, International Journal of Electronic Commerce, Electronic Markets, the International Conference on Information Systems, the European Conference on Information Systems, and working conferences of IFIP. He is currently an associate editor of Information Systems Journal and president of the Irish Association for Information Systems. He can be reached at p.finnegan@ucc.ie.

Olof Nilsson is a senior lecturer in Social Informatics at Mid Sweden University and, during 2008, a Post-Doctoral Research Fellow at University College Cork, Ireland. His research has been focused on access to public information systems, and he has taken an active part in two "triple helix" projects developing open source applications for public authorities. His research on access has been published in International Journal of Public Information Systems, in a forthcoming edition of International Journal for Humanistic and Social Computing, and also in a number of international conference proceedings. He is currently researching how open source and open innovation facilitates changes to the traditional approach to public service and government in Sweden. He can be reached at o.nilsson@ucc.ie. 